\title{
An Early (Sixth-Hour) Serum Bilirubin Measurement Is Useful in Predicting the Development of Significant Hyperbilirubinemia and Severe ABO Hemolytic Disease in a Selective High-Risk Population of Newborns With ABO Incompatibility
}

\author{
S. Ümit Sarici, MD*; Murat Yurdakök, MD*; Muhittin A. Serdar, MDł; Olcay Oran, MD*; \\ Gülşen Erdem, MD*; Gülsevin Tekinalp, $\mathrm{MD}^{*}$; and Şule Yiğit, $\mathrm{MD}^{*}$
}

\begin{abstract}
Objective. In the era of early discharge of newborns from the hospital, newborns with $\mathrm{ABO}$ incompatibility are at especially greater risk for developing a subsequent significant hyperbilirubinemia because some of these infants also may present with some degree of $\mathrm{ABO}$ isoimmune disease. In this study, we aimed to determine prospectively the critical serum total bilirubin level to predict significant hyperbilirubinemia and severe hemolytic disease in healthy term newborns with ABO incompatibility based on a serum bilirubin measurement made at a postnatal age at which all newborns are at the hospital before discharge and at which any therapeutic intervention, if necessary, could be started as early as possible.
\end{abstract}

Methods. A total of 136 healthy term newborns with ABO (O-A or O-B) blood group incompatibility were followed prospectively with daily serum total bilirubin measurements for the first 5 days of life. Newborns with serum total bilirubin levels of $\geq 5 \mathrm{mg} / \mathrm{dL}$ and an increase in serum total bilirubin concentration of $>0.5 \mathrm{mg} / \mathrm{dL} / \mathrm{h}$ in the first 24 hours, $\geq 12 \mathrm{mg} / \mathrm{dL}$ on day $2, \geq 15 \mathrm{mg} / \mathrm{dL}$ on day 3 , and $\geq 17 \mathrm{mg} / \mathrm{dL}$ on days 4 and 5 were defined to have significant hyperbilirubinemia and were started on phototherapy treatment. Additional treatment modalities, including intense phototherapy, intravenous immunoglobulin treatment, and exchange transfusion, were used when serum bilirubin concentrations exceeded $20 \mathrm{mg} / \mathrm{dL}$ or increased by $>1 \mathrm{mg} / \mathrm{dL} / \mathrm{h}$ despite a phototherapy treatment of at least 4 hours. The additional assessment of the predictive ability of the sixth-hour serum total bilirubin value in determining the development of significant hyperbilirubinemia was made on the basis of the placement of any of the first 5 days' serum bilirubin measurements in the $\geq 90$ th percentile of the study population. On the basis of the percentile tracks constructed from the 10th, 35 th, 50th, 60th, and 90th percentiles of serum total bilirubin values, a nomogram demonstrating the 3 percentile tracks as risk zone demarcators with divided risk zones was produced.

Results. Twenty-nine newborns (21.3\%) had significant hyperbilirubinemia. There were significant differences between the newborns who did and the newborns who did not develop significant hyperbilirubinemia

From the ${ }^{*}$ Division of Neonatology, Department of Pediatrics, Hacettepe University Faculty of Medicine İhsan Doğramaci Children's Hospital, Ankara, Turkey; and 捛epartment of Clinical Biochemistry, Gülhane Military Medical Academy, Ankara, Turkey.

Received for publication May 9, 2001; accepted Dec 13, 2001

Reprint requests to (S.Ü.S.) P.K. 660, Yenişehir-06445, Ankara, Turkey. E-mail: susarici@hotmail.com

PEDIATRICS (ISSN 0031 4005). Copyright (C) 2002 by the American Academy of Pediatrics. with respect to the reticulocyte count $(4.39 \pm 3.46 \%$ vs $2.95 \pm 1.63)$ and the presence of a direct antiglobulin test positivity (6 of 23 vs 0 of 107) and a sibling with neonatal jaundice ( 6 of 23 vs 5 of 102). A mean serum bilirubin level of $\geq 4 \mathrm{mg} / \mathrm{dL}$ at the sixth hour of life was determined to have the highest sensitivity $(86.2 \%)$ and negative predictive value $(94.5 \%)$ and a positive predictive value of $39.7 \%$ to predict the newborns who would develop significant hyperbilirubinemia. At the mean serum bilirubin level of $6 \mathrm{mg} / \mathrm{dL}$, the sensitivity, specificity, and negative and positive predictive values were $100 \%$, $91.5 \%, 100 \%$, and $35.3 \%$, respectively, in diagnosing 6 cases of severe ABO hemolytic disease. On the hour (age)-specific percentile-based nomogram, the zone above the 90th percentile was determined as high risk and that below the 35 th percentile as low risk.

Conclusions. The reticulocyte count, a positive direct antiglobulin test, and the presence of a sibling with neonatal jaundice were determined to be the good predictors for the development of significant hyperbilirubinemia and severe hemolytic disease of the newborn. A serum bilirubin measurement and the use of the critical bilirubin levels of $4 \mathrm{mg} / \mathrm{dL}$ and $6 \mathrm{mg} / \mathrm{dL}$ at the sixth hour of life will predict nearly all newborns who will have significant hyperbilirubinemia and those who will develop severe hemolytic disease of the newborn, respectively. An hour (age)-specific percentile-based nomogram can be used to predict which newborn is at high risk ( $\geq 90$ th percentile), intermediate risk (35th-90th percentiles), and low risk ( $<35$ th percentile) for developing significant hyperbilirubinemia. The 35th and 90th percentile tracks, approximating the serum bilirubin levels of $3.3 \mathrm{mg} / \mathrm{dL}$ and $6.5 \mathrm{mg} / \mathrm{dL}$ at the sixth hour of life, respectively, can be used as safe risk demarcators in deciding about the time of discharge of ABO-incompatible newborns from the hospital. Pediatrics 2002;109(4). URL: http://www.pediatrics.org/cgi/content/full/109/4/ e53; ABO incompatibility, early discharge, hyperbilirubinemia, newborn, prediction.

ABBREVIATION. ROC, receiver operating characteristic.

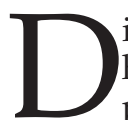
ischarging healthy term newborns from the hospital after delivery at increasingly earlier postnatal ages has recently become a common practice for medical, social, and economic reasons. However, it has been shown that newborns whose postdelivery hospital stay is $\leq 72$ hours are at a significantly greater risk for readmission than those whose stay is $>72$ hours. ${ }^{1-5}$ Hyperbilirubinemia is 
the most commonly reported cause for readmission during the early neonatal period, ${ }^{1-3,5-9}$ and $0.36 \%$ of healthy term newborns discharged after 72 hours of life with no more than mild hyperbilirubinemia may even develop a subsequent moderate to severe hyperbilirubinemia. ${ }^{6}$ In the United States, there were 22 reported cases of kernicterus developing after discharge within 48 hours of birth between 1991 and 1995. ${ }^{10}$ Furthermore, the safety of relying on follow-up visits after early discharge is questionable because $10 \%$ of the population fails to return for a follow-up visit. ${ }^{11}$ Thus, a few recent studies, most of which did not include cases of $\mathrm{ABO}$ and/or Rh incompatibility, investigated the value of first-day bilirubin measurement in predicting the subsequent development of significant hyperbilirubinemia in healthy term newborns, ${ }^{12-15}$ because early prediction and detection of threatening bilirubin levels permit initiation of phototherapy and prevent higher risks and cost of other therapies and kernicterus.

ABO incompatibility occurs in $15 \%$ to $20 \%$ of all pregnancies and produces a spectrum of hemolytic disease, the extreme end of which is recognized as $\mathrm{ABO}$ hemolytic disease. ${ }^{16}$ Several cord blood parameters have been studied in an attempt to anticipate the clinical course of a newborn with ABO incompatibility; however, to our knowledge, no study has evaluated the usefulness of first-day bilirubin measurement in predicting the subsequent clinical course and development of significant hyperbilirubinemia in newborns who have $\mathrm{ABO}$ incompatibility and are at relatively greater risk for having a severe jaundice.

In this study, we therefore investigated the value of first-day (sixth-hour) bilirubin measurement in predicting the development of significant hyperbilirubinemia later during the first days of life in a selective high-risk population of newborns with $\mathrm{ABO}$ incompatibility by measuring serum bilirubin levels daily for the first 5 days of life.

\section{METHODS}

This study was performed at the Division of Neonatology of Hacettepe University Faculty of Medicine between June 2000 and March 2001. All healthy full-term ( $\geq 38$ weeks' gestation) newborns with blood group system of groups A or B born to mothers with blood group $\mathrm{O}$ without a simultaneous Rhesus blood factor incompatibility at this hospital through this period were enrolled prospectively in the study.

Hematocrit and reticulocyte counts, blood group including Rhesus, a direct antiglobulin (Coombs) test, glucose-6-phosphate dehydrogenase activity, and serum direct and indirect bilirubin levels were performed routinely in all cases. Serum total bilirubin measurements were initially made at the sixth hour of life and were repeated daily for the next 4 days; each measurement was performed just 24 hours after the previous measurement. Newborns with serum total bilirubin levels of $\geq 5 \mathrm{mg} / \mathrm{dL}$ and an increase in serum total bilirubin concentration of $>0.5 \mathrm{mg} / \mathrm{dL} / \mathrm{h}$ in the first 24 hours, $\geq 12 \mathrm{mg} / \mathrm{dL}$ on day $2, \geq 15 \mathrm{mg} / \mathrm{dL}$ on day 3 , and $\geq 17 \mathrm{mg} / \mathrm{dL}$ on days 4 and 5 were defined to have significant hyperbilirubinemia ${ }^{17}$ and were started on phototherapy treatment. Additional treatment modalities, including intense phototherapy, ${ }^{18}$ intravenous immunoglobulin treatment, ${ }^{19}$ and exchange transfusion, were used when serum bilirubin concentrations exceeded $20 \mathrm{mg} / \mathrm{dL}$ or increased by $>1 \mathrm{mg} / \mathrm{dL} / \mathrm{h}$ despite a phototherapy treatment of at least 4 hours. In all cases, gender; birth weight; gestational age; delivery route; feeding pattern; maternal age; Apgar scores; whether the mother smoked or had any chronic diseases (hypertension, diabetes mellitus, etc) before or during gestation; and whether there was enclosed hem- orrhage, abnormal weight loss, or any siblings with neonatal jaundice were recorded. Informed consent was obtained from all parents of the newborns in the study.

Statistical data were analyzed with the independent sample $t$ test and the descriptive analysis and $\chi^{2}$ tests. The critical serum total bilirubin levels measured at the sixth hour of life with different sensitivity and specificity values were determined with the receiver operating characteristic (ROC) curve analysis. The additional assessment of the predictive ability of the sixth-hour serum total bilirubin value in determining the development of significant hyperbilirubinemia was made on the basis of the placement of any of the first 5 days' serum bilirubin measurements in the $\geq 90$ th percentile of the study population. A Gaussian distribution curve was obtained by determining the distribution of the population according to the mean serum total bilirubin values measured at the specific hours (daily serum bilirubin measurements). The 10th, 35th, 50th, 60th, and 90th percentiles of serum total bilirubin values were determined from the Gaussian distribution and connected as percentile tracks. On the basis of the percentile tracks, which give the highest sensitivity, specificity, and negative and positive predictive values, a nomogram demonstrating the 3 percentile tracks as risk zone demarcators with divided risk zones was produced. The zone above the 90th percentile was labeled as high risk, and that below the 35th percentile was labeled as low risk. Serum total bilirubin values between the 35th and 90th percentiles were designated as being in the intermediate-risk zone; this zone was subdivided further by the 60th percentile into highand low-intermediate risk zones.

\section{RESULTS}

A total of 150 newborns were initially enrolled in the study, but 14 of these were excluded during the study because some of them were transferred to our neonatal intensive care unit as a result of various diagnoses or because some of the parents did not want to continue participating in the study. During the study period, 1014 full-term infants were born, and the incidence of $\mathrm{ABO}(\mathrm{O}-\mathrm{A}$ and $\mathrm{O}-\mathrm{B})$ incompatibility was $14.8 \%$.

Twenty-nine newborns (21.3\%) had significant hyperbilirubinemia with any of the 5 days' serum bilirubin levels exceeding the threshold levels defined for phototherapy. When the first 5 days' mean bilirubin levels of the newborns who did and the newborns who did not develop significant hyperbilirubinemia were compared, the newborns who later developed significant hyperbilirubinemia had significantly higher bilirubin levels on each day (Table 1).

Demographic characteristics of the newborns who did and the newborns who did not develop significant hyperbilirubinemia are shown in Table 2. Various factors that may be associated with the risk of developing hyperbilirubinemia, including hematocrit, type of $\mathrm{ABO}$ blood group incompatibility (O-A or $\mathrm{O}-\mathrm{B})$, gender, birth weight, gestational age, maternal smoking, delivery route, feeding pattern, enclosed hemorrhage, and abnormal weight loss at the end of 5 days, did not significantly differ, whereas the reticulocyte count and the presence of a direct antiglobulin test positivity and a sibling with neonatal jaundice were significantly different between the newborns who did and the newborns who did not develop significant hyperbilirubinemia (Table 2).

With a ROC analysis, a mean serum bilirubin level of $\geq 4 \mathrm{mg} / \mathrm{dL}$ at the sixth hour of life was determined to have the highest sensitivity $(86.2 \%)$ to predict the newborns who would develop significant hyperbilirubinemia (Fig 1). At this critical mean serum bilirubin level, the negative predictive value was very 
TABLE 1. First 5 Days' Bilirubin Levels of the Newborns Who Did and Who Did Not Develop Significant Hyperbilirubinemia*

\begin{tabular}{cccccc}
\hline & Day 1 & Day 2 & Day 3 & Day 4 & Day 5 \\
\hline Newborns with significant & $6.0 \pm 2.08$ & $11.0 \pm 2.71$ & $14.64 \pm 2.75$ & $15.93 \pm 2.14$ & $15.98 \pm 2.82$ \\
hyperbilirubinemia $(n=29)$ & $(5.21-6.79)$ & $(9.96-12.03)$ & $(13.6-15.69)$ & $(15.11-16.74)$ & $(14.91-17.06)$ \\
Newborns without significant & $3.63 \pm 1.0$ & $7.09 \pm 2.05$ & $9.59 \pm 2.65$ & $10.85 \pm 3.36$ & $10.88 \pm 3.81$ \\
hyperbilirubinemia $(n=107)$ & $(3.44-3.82)$ & $(6.69-7.48)$ & $(9.08-10.09)$ & $(10.21-11.5)$ & $(10.15-11.61)$ \\
$P$ value & $<.001$ & $<.001$ & $<.001$ & $<.001$ & $<.001$ \\
\hline
\end{tabular}

* Values (bilirubin, $\mathrm{mg} / \mathrm{dL}$ ) are given as mean \pm standard deviation with $95 \%$ confidence interval.

TABLE 2. Demographic Characteristics of Newborns Who Did and Who Did Not Develop Significant Hyperbilirubinemia

\begin{tabular}{|c|c|c|c|}
\hline Demographics & $\begin{array}{c}\text { Newborns With Significant } \\
\text { Hyperbilirubinemia } \\
(n=29)\end{array}$ & $\begin{array}{c}\text { Newborns Without Significant } \\
\text { Hyperbilirubinemia } \\
(n=107)\end{array}$ & $\begin{array}{c}P \\
\text { Value }\end{array}$ \\
\hline Hematocrit $(\%)^{*}$ & $55.38 \pm 6.47$ & $57.05 \pm 3.8$ & .193 \\
\hline Reticulocyte $(\%)^{*}$ & $4.39 \pm 3.46$ & $2.95 \pm 1.63$ & .037 \\
\hline Direct antiglobulin test (positive/negative) & $6 / 23$ & $0 / 107$ & $<.001$ \\
\hline Type of ABO blood group incompatibility $(\mathrm{O}-\mathrm{A} / \mathrm{O}-\mathrm{B})$ & $21 / 8$ & $70 / 37$ & .478 \\
\hline Gender (male/female) & $15 / 14$ & $54 / 53$ & .904 \\
\hline Gestational age $(w k)^{*}$ & $39.21 \pm 1.18$ & $39.45 \pm 1.18$ & .759 \\
\hline Apgar score* & $9.52 \pm 0.69$ & $9.62 \pm 0.72$ & .507 \\
\hline Enclosed hemorrhage (present/absent) & $1 / 28$ & $2 / 105$ & .516 \\
\hline Birth weight $(\mathrm{g})^{*}$ & $3214 \pm 828$ & $3212 \pm 196$ & .975 \\
\hline Delivery mode (vaginal/cesarean) & $15 / 14$ & $59 / 48$ & .743 \\
\hline $\begin{array}{l}\text { Abnormal ( } \geq 10 \%) \text { weight loss at the end } \\
\text { of first } 5 \mathrm{~d} \text { (present/absent) }\end{array}$ & $4 / 25$ & $13 / 94$ & .759 \\
\hline Any sibling with neonatal jaundice (present/absent) & $6 / 23$ & $5 / 102$ & .012 \\
\hline Maternal age $(y)^{*}$ & $29.76 \pm 5.9$ & $28.96 \pm 5.5$ & .498 \\
\hline \multicolumn{4}{|l|}{ Feeding pattern } \\
\hline Breast milk & 25 & 96 & .690 \\
\hline Formula milk & - & 1 & \\
\hline Partially breast milk & 4 & 10 & \\
\hline $\begin{array}{l}\text { Maternal chronic disease acquired before or } \\
\text { during gestation (present/absent) }\end{array}$ & $1 / 28$ & $6 / 101$ & .538 \\
\hline Maternal gestational smoking (present/absent) & $2 / 27$ & $9 / 98$ & .572 \\
\hline
\end{tabular}

* Values are given as mean \pm standard deviation.

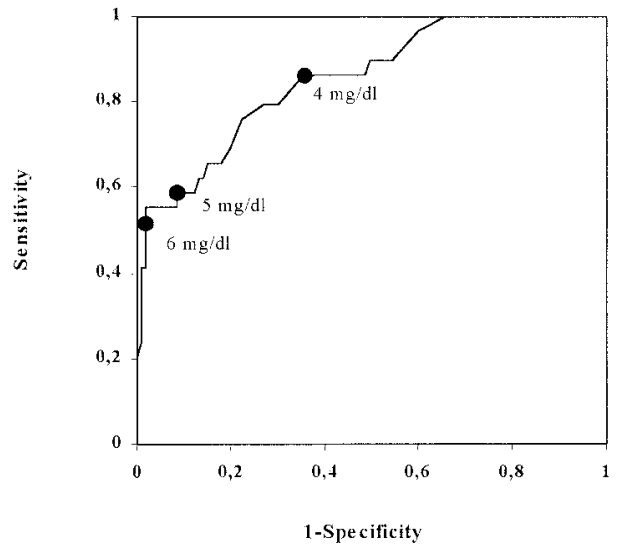

Fig 1. The ROC analysis of the various serum bilirubin levels at the sixth hour of life in predicting the development of significant hyperbilirubinemia during the first 5 days of life.

high (94.5\%) and the positive predictive value was $39.7 \%$ (Table 3). Of the 63 newborns who had a serum total bilirubin level of $\geq 4 \mathrm{mg} / \mathrm{dL}$ at the sixth hour of life, 25 (39.7\%) subsequently developed significant hyperbilirubinemia, whereas only 4 of the 73 newborns $(5.5 \%)$ who had a serum total bilirubin level of $<4 \mathrm{mg} / \mathrm{dL}$ at the sixth hour developed significant hyperbilirubinemia later during the first 5 days of life (Fig 2, Table 3).

During the study period, 6 of the 29 newborns who underwent phototherapy as a result of significant hyperbilirubinemia had increasing serum bilirubin levels despite phototherapy, and these newborns were administered additional treatment modalities: intense phototherapy and intravenous immunoglobulin $(n=5)$ and plus exchange transfusion $(n=1)$. All of these newborns had higher bilirubin levels and reticulocyte counts than the other newborns; all had a positive direct antiglobulin test, and 5 of 6 had a sibling with neonatal jaundice. These newborns thus were deemed to have severe hemolytic disease as a result of $\mathrm{ABO}$ incompatibility. Of the 119 newborns who had a serum bilirubin level of $<6 \mathrm{mg} / \mathrm{dL}$ at the sixth hour of life, 14 underwent phototherapy for developing significant hyperbilirubinemia, and none of these required any of the additional treatment modalities. In contrast, of the 17 newborns who had a serum bilirubin level of $\geq 6 \mathrm{mg} / \mathrm{dL}$ at the sixth hour of life, only 2 newborns did not develop significant hyperbilirubinemia, and of the 15 newborns who underwent phototherapy, 6 required at least 1 of the additional treatment modalities. At the mean serum bilirubin level of $6 \mathrm{mg} / \mathrm{dL}$ at the sixth hour of life, the sensitivity, specificity, and negative and positive predictive values were $100 \%, 91.5 \%, 100 \%$, and $35.3 \%$, respectively, in diagnosing severe hemolytic disease of the newborn as a result of $\mathrm{ABO}$ incompatibility.

In an additional assessment of the predictive ability of the sixth-hour serum bilirubin value in determining the development of significant hyperbilirubinemia on an hour (age)-specific percentile-based 
TABLE 3. Sensitivity, Specificity, and Positive and Negative Predictive Values of Various Serum Bilirubin Levels at the Sixth Hour of Life in Predicting the Development of Significant Hyperbilirubinemia*

\begin{tabular}{|c|c|c|c|c|c|c|c|c|}
\hline $\begin{array}{c}\text { Serum } \\
\text { Bilirubin } \\
\text { Level at the } \\
\text { Sixth Hour }\end{array}$ & $\begin{array}{c}\text { False- } \\
\text { Negatives } \\
(n[\%])\end{array}$ & $\begin{array}{c}\text { True- } \\
\text { Positives } \\
(n[\%])\end{array}$ & $\begin{array}{c}\text { True- } \\
\text { Negatives } \\
(n[\%])\end{array}$ & $\begin{array}{l}\text { False- } \\
\text { Positives } \\
(n[\%])\end{array}$ & $\begin{array}{c}\text { Sensitivity } \\
(\%)\end{array}$ & $\begin{array}{c}\text { Specificity } \\
(\%)\end{array}$ & $\begin{array}{c}\text { Positive } \\
\text { Predictive } \\
\text { Value (\%) }\end{array}$ & $\begin{array}{l}\text { Negative } \\
\text { Predictive } \\
\text { Value (\%) }\end{array}$ \\
\hline $4 \mathrm{mg} / \mathrm{dL}$ & $\begin{array}{c}4(2.9) \\
(0.1-5.7)\end{array}$ & $\begin{array}{c}25(18.4) \\
(11.9-24.9)\end{array}$ & $\begin{array}{c}69(50.7) \\
(42.3-59.1)\end{array}$ & $\begin{array}{c}38(27.9) \\
(20.3-35.4)\end{array}$ & 86.2 & 64.5 & 39.7 & 94.5 \\
\hline $5 \mathrm{mg} / \mathrm{dL}$ & $\begin{array}{c}12(8.8) \\
(4.0-13.5)\end{array}$ & $\begin{array}{c}17(12.5) \\
(16.9-18.1)\end{array}$ & $\begin{array}{r}97(71.3) \\
(63.7-78.9)\end{array}$ & $\begin{array}{l}10(7.4) \\
(3.0-11.8)\end{array}$ & 58.6 & 90.7 & 62.9 & 89.0 \\
\hline $6 \mathrm{mg} / \mathrm{dL}$ & $\begin{array}{c}14(10.3) \\
(5.2-15.4)\end{array}$ & $\begin{array}{l}15(11.0) \\
(5.7-16.3)\end{array}$ & $\begin{array}{c}105(77.2) \\
(70.1-84.2)\end{array}$ & $\begin{array}{l}2(1.5) \\
(0-3.5)\end{array}$ & 51.7 & 98.1 & 88.2 & 88.2 \\
\hline
\end{tabular}

* Values in parantheses indicate the lower and upper bounds of the $95 \%$ confidence interval.

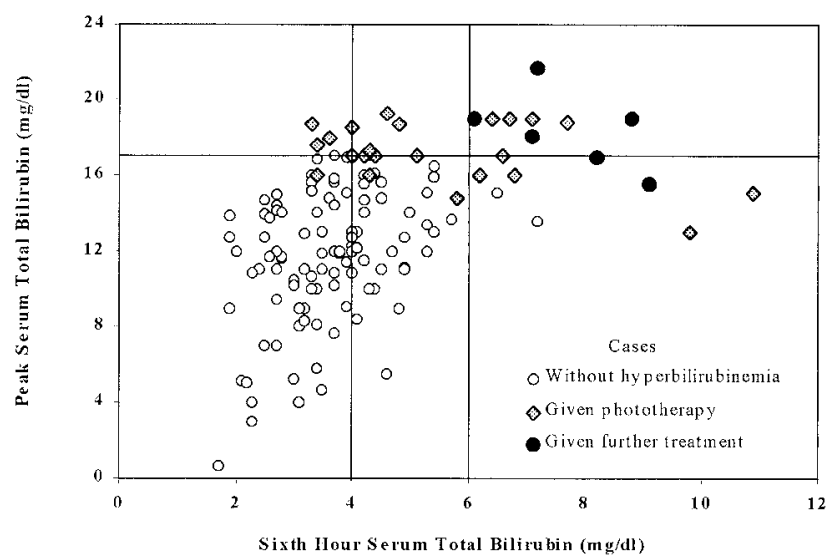

Fig 2. The schematic representation of the relationship between the sixth-hour critical serum bilirubin levels of $4 \mathrm{mg} / \mathrm{dL}$ and 6 $\mathrm{mg} / \mathrm{dL}$ and the development of significant hyperbilirubinemia requiring phototherapy and an additional treatment modality.

nomogram, the 35 th, 60 th, and 90 th percentile tracks determined by means of the highest sensitivity, specificity, and negative and positive predictive values were used as risk zone demarcators (Fig 3, Table 4). Serum total bilirubin levels of $\geq 10.7 \mathrm{mg} / \mathrm{dL}$ at 24 hours, $\geq 14.2 \mathrm{mg} / \mathrm{dL}$ at 48 hours, and $\geq 16.5 \mathrm{mg} / \mathrm{dL}$ at 72 hours of age were above the 90th percentile for postnatal age in hours.

The critical serum total bilirubin levels of 3.3 $\mathrm{mg} / \mathrm{dL}$ and $6.5 \mathrm{mg} / \mathrm{dL}$ at the sixth hour of life had

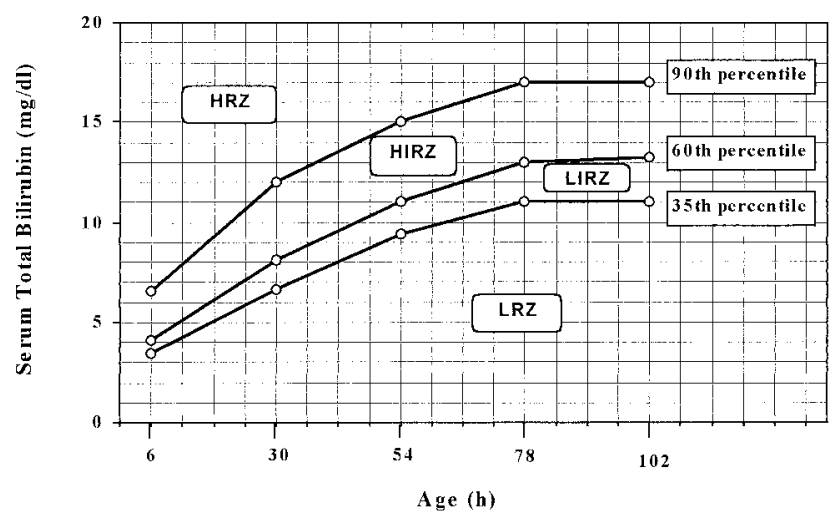

Fig 3. Risk designation of newborns according to the percentile tracks based on the age-specific serum bilirubin values. HRZ, high-risk zone designated above the 90th percentile track; HIRZ, high intermediate-risk zone between the 60th and 90th percentiles; LIRZ, low intermediate-risk zone between the 60th and 35th percentiles; LRZ, low-risk zone below the 35th percentile track. the highest $(100 \%)$ sensitivity and specificity, respectively, thus approximating the 35th and 90th percentiles on the nomogram, respectively (Fig 3, Table 4).

\section{DISCUSSION}

Considering that severe jaundice and kernicterus can occur in even some full-term healthy newborns with no apparent hemolysis or jaundice in the first 24 hours of life, $, 20,21$ the prediction of a probable future hyperbilirubinemia in newborns discharged from the hospital in the era of early discharge gains much more importance than ever. Although various parameters, including cord blood bilirubin and antiglobulin test and maternal isoimmune antibody titers, have been studied to predict the clinical course of a newborn with $\mathrm{ABO}$ incompatibility, 22,23 the development and severity of a subsequent hyperbilirubinemia or isoimmune disease remain difficult to anticipate because there is no test that is of high predictive value. ${ }^{24}$ We therefore aimed in this study to determine prospectively the critical serum total bilirubin level to predict significant hyperbilirubinemia and severe hemolytic disease in healthy term newborns with $\mathrm{ABO}$ incompatibility on the basis of a serum bilirubin measurement made at a postnatal age at which all newborns are at the hospital before discharge and at which any therapeutic intervention, if necessary, could be started as early as possible or appropriate follow-up programs could be implemented in the high-risk groups in the absence of possibility of early treatment modalities.

The incidences of $\mathrm{ABO}$ incompatibility (14.8\%), significant hyperbilirubinemia in $\mathrm{ABO}$ incompatibility $(21.3 \%)$, and severe hemolytic disease of the newborn as a result of $\mathrm{ABO}$ incompatibility $(4.4 \%)$ in this study population of infants with type O-A and type $\mathrm{O}-\mathrm{B}$ incompatibility were reportedly in accordance with the incidence and epidemiology of ABO incompatibility. ${ }^{16,25}$ The incidence of significant hyperbilirubinemia in our study $(21.3 \%)$ is much higher than that reported in the general population. ${ }^{13-15}$ This may be attributable to the ethnic and geographic characteristics of our population, because a previous study performed on healthy term Turkish newborns ${ }^{12}$ also showed a higher incidence of significant hyperbilirubinemia $(12.05 \%)$ than that reported in other parts of the world. In that previous study performed in Ankara, ${ }^{12} 498$ full-term newborns were followed prospectively during the first 5 days of life, and the critical serum bilirubin level of $6 \mathrm{mg} / \mathrm{dL}$ 
TABLE 4. Sensitivity, Specificity, and Positive and Negative Predictive Values of the Percentile Tracks as Risk Demarcators in Predicting the Development of Significant Hyperbilirubinemia*

\begin{tabular}{|c|c|c|c|c|c|c|c|c|}
\hline $\begin{array}{c}\text { Percentile } \\
\text { Track as Risk } \\
\text { Demarcator }\end{array}$ & $\begin{array}{c}\text { False- } \\
\text { Negatives } \\
(n[\%])\end{array}$ & $\begin{array}{l}\text { True- } \\
\text { Positives } \\
(n[\%])\end{array}$ & $\begin{array}{c}\text { True- } \\
\text { Negatives } \\
(n[\%])\end{array}$ & $\begin{array}{l}\text { False- } \\
\text { Positives } \\
(n[\%])\end{array}$ & $\begin{array}{l}\text { Sensitivity } \\
(\%)\end{array}$ & $\begin{array}{c}\text { Specificity } \\
(\%)\end{array}$ & $\begin{array}{l}\text { Positive } \\
\text { Predictive } \\
\text { Value (\%) }\end{array}$ & $\begin{array}{l}\text { Negative } \\
\text { Predictive } \\
\text { Value (\%) }\end{array}$ \\
\hline 90th percentile & $\begin{array}{l}17(12.5) \\
(6.9-18.0)\end{array}$ & $\begin{array}{l}12(8.8) \\
(4.0-13.6)\end{array}$ & $\begin{array}{c}106(77.9) \\
(70.9-84.9)\end{array}$ & $\begin{array}{c}1(0.7) \\
(0-2.1)\end{array}$ & 41.4 & 99.0 & 92.3 & 86.2 \\
\hline 60th percentile & $\begin{array}{c}6(4.4) \\
(0.9-7.8)\end{array}$ & $\begin{array}{c}23(16.9) \\
(10.6-23.2)\end{array}$ & $\begin{array}{c}78(57.4) \\
(49.1-65.7)\end{array}$ & $\begin{array}{c}29(21.3) \\
(14.4-28.2)\end{array}$ & 79.3 & 72.9 & 44.2 & 92.9 \\
\hline 35th percentile & $\begin{array}{l}0(0) \\
(0-0)\end{array}$ & $\begin{array}{c}29(21.3) \\
(14.4-28.2)\end{array}$ & $\begin{array}{r}43(31.6) \\
(23.8-39.4)\end{array}$ & $\begin{array}{c}64(47.1) \\
(38.7-55.5)\end{array}$ & 100 & 40.2 & 31.2 & 100 \\
\hline
\end{tabular}

* Values in parantheses indicate the lower and upper bounds of the $95 \%$ confidence interval.

measured in the first 24 hours (6.2-21.4) of life had the highest sensitivity $(90 \%)$ and negative predictive value $(97.9 \%)$ in determining the newborns who would have significant hyperbilirubinemia and the newborns who would require phototherapy treatment. When we compared the newborns with significant hyperbilirubinemia in the 2 studies conducted in the same region of Turkey, the critical serum bilirubin level that had the highest sensitivity and negative predictive value in the present study was lower than that in the previous study $(4 \mathrm{mg} / \mathrm{dL}$ vs 6 $\mathrm{mg} / \mathrm{dL}$ ), although the first serum bilirubin measurement was not made at a uniform hour in that study. This difference must be attributable to the higher incidence of significant hyperbilirubinemia in the present study $(21.3 \%$ vs $12.05 \%)$ resulting from the risk of $\mathrm{ABO}$ incompatibility. When we compared the newborns who did not have significant hyperbilirubinemia in these 2 studies, the first 5 days' mean serum bilirubin levels $(5.04 \pm 1.79 \mathrm{mg} / \mathrm{dL}, 7.85 \pm$ $2.41 \mathrm{mg} / \mathrm{dL}, 10.09 \pm 1.13 \mathrm{mg} / \mathrm{dL}, 11.37 \pm 2.82 \mathrm{mg} /$ $\mathrm{dL}, 12.46 \pm 2.03 \mathrm{mg} / \mathrm{dL}$, respectively) in the previous study ${ }^{12}$ were very similar to those in the present study. Nevertheless, the mean serum bilirubin levels of the newborns with significant hyperbilirubinemia and of the newborns without significant hyperbilirubinemia in both studies performed in Central Anatolia were significantly higher than those reported in other regions of the world, further confirming the possible role of ethnic and geographic characteristics of the population in the development of hyperbilirubinemia. Bhutani et al, ${ }^{13}$ in their first study, prospectively followed 1097 newborns during the first 5 days of life and reported an incidence of $4.6 \%$ for significant hyperbilirubinemia ( $\geq 17 \mathrm{mg} / \mathrm{dL}$ ). According to the serum bilirubin levels measured at 20 to 28 hours of life, the critical serum bilirubin levels of $5 \mathrm{mg} / \mathrm{dL}$ and $6 \mathrm{mg} / \mathrm{dL}$ had the highest sensitivity $(100 \%)$ and specificity $(80.1 \%)$, respectively.

In the present study, 6 newborns were considered to have severe $\mathrm{ABO}$ hemolytic disease because they met several of the hemolysis criteria, such as early onset hyperbilirubinemia, a positive direct antiglobulin test, and reticulocytosis, and because they did not respond to initial phototherapy treatment. However, if we defined $\mathrm{ABO}$ hemolytic disease with a single criterion, jaundice in the first 24 hours, reportedly being as one of the most important hallmarks of hemolytic disease of the newborn as a result of $\mathrm{ABO}$ incompatibility, ${ }^{26}$ then we would have a total of 17 cases with $\mathrm{ABO}$ hemolytic disease, although not all of them were severe, because they all had a serum bilirubin level of $\geq 6 \mathrm{mg} / \mathrm{dL}$ at the sixth hour of life.

Seidman et al ${ }^{14}$ also followed 1177 term newborns during the first 5 days of life by measuring serum bilirubin levels daily. Their first bilirubin measurement time was between 8 and 24 hours of life, and their threshold levels for defining significant hyperbilirubinemia were similar (total serum bilirubin of $>10 \mathrm{mg} / \mathrm{dL}$ on day $2,>14 \mathrm{mg} / \mathrm{dL}$ on day 3 , and $>17$ $\mathrm{mg} / \mathrm{dL}$ on days 4 and 5 of life) to the criteria that we used in our study. In their study, the risk of significant hyperbilirubinemia was $5.1 \%$ and the critical serum bilirubin level of $5 \mathrm{mg} / \mathrm{dL}$ was reported to have the sensitivity and specificity of $63.1 \%$ and $94.2 \%$, respectively, for detecting significant hyperbilirubinemia. According to our findings, $86.2 \%$ of the newborns who later developed significant hyperbilirubinemia had a sixth-hour serum bilirubin level of $\geq 4 \mathrm{mg} / \mathrm{dL}$ and $64.5 \%$ of newborns who later did not develop significant hyperbilirubinemia had a sixth-hour serum bilirubin level of $<4 \mathrm{mg} / \mathrm{dL}$.

In a previous study that constructed a similar percentile-based nomogram in 2840 newborns, ${ }^{15}$ significant hyperbilirubinemia was defined as the presence of any total serum bilirubin level reaching into the high-risk zone ( $\geq 95$ th percentile track), and the predictive ability of the 40th percentile track as the risk demarcator had the highest $(100 \%)$ sensitivity and negative predictive value. To define risk groups for hyperbilirubinemia according to the percentiles of the study population, to make it possible making an instantaneous evaluation of the risk status on an age-specific basis without the need to follow any newborn for respective days, and to detect the critical serum bilirubin levels that had the highest $(100 \%)$ sensitivity and specificity, we constructed an age (hour)-specific percentile-based bilirubin nomogram from our data. On this age-specific nomogram, the 35th percentile (serum bilirubin of $3.3 \mathrm{mg} / \mathrm{dL}$ at the sixth hour of life) and 90th percentile (serum bilirubin of $6.5 \mathrm{mg} / \mathrm{dL}$ at the sixth hour of life) had the highest $(100 \%)$ sensitivity and negative predictive value, and the highest (99\%) specificity, respectively. These findings indicate that newborns who will later develop significant hyperbilirubinemia have serum bilirubin levels above the 35 th percentile track $(\geq 3.3$ $\mathrm{mg} / \mathrm{dL}$ at the sixth hour of age), and most newborns with serum bilirubin levels below the 35th percentile track $(<3.3 \mathrm{mg} / \mathrm{dL}$ at the sixth hour of age) will not have significant hyperbilirubinemia.

Two findings of hemolysis (reticulocytosis and a 
positive direct antiglobulin test) and the history of a sibling who had jaundice in the neonatal period were significantly more prominent in the newborns who later required phototherapy treatment in the present study. In analysis of the consecutive pregnancies of 230 primigravid mothers whose first offspring had hemolytic disease of the newborn as a result of $\mathrm{ABO}$ incompatibility, $\mathrm{ABO}$ hemolytic disease recurred in $88 \%$ of their next offspring who had incompatibility, and $62 \%$ of these required treatment. ${ }^{27}$

The reticulocyte count, a positive direct antiglobulin test, and the presence of a sibling with neonatal jaundice were determined to be the good predictors for the development of significant hyperbilirubinemia and severe hemolytic disease of the newborn in a selective high-risk population of full-term healthy newborns with $\mathrm{ABO}$ incompatibility in this study. A serum bilirubin measurement and the use of the critical bilirubin levels of $4 \mathrm{mg} / \mathrm{dL}$ and 6 $\mathrm{mg} / \mathrm{dL}$ at the sixth hour of life will predict nearly all newborns who will have significant hyperbilirubinemia and those who will develop severe hemolytic disease of the newborn, respectively. To make a more sensitive and more specific evaluation considering the percentile distribution of serum bilirubin levels for postnatal age, an hour (age)-specific percentile-based nomogram constructed from daily serum bilirubin values of newborns followed during the first 5 days of life can be used to predict which newborn is at high risk ( $\geq 90$ th percentile), intermediate risk (35th-90th percentiles), and low risk $(<35$ th percentile) for developing significant hyperbilirubinemia. According to age-specific nomogram determined in this study, 35th and 90th percentile tracks, approximating the serum bilirubin levels of $3.3 \mathrm{mg} / \mathrm{dL}$ and $6.5 \mathrm{mg} / \mathrm{dL}$ at the sixth hour of life, respectively, can be used as safe risk demarcators in deciding about the time of discharge of ABO-incompatible newborns from the hospital. However, results of the present study should be confirmed in additional studies that include larger numbers of newborns with significant hyperbilirubinemia and hemolytic disease of the newborn.

\section{REFERENCES}

1. Maisels MJ, Kring E. Length of stay, jaundice, and hospital readmission. Pediatrics. 1998;101:995-998

2. Lee K-S, Perlman M, Ballantyne M. Association between duration of neonatal hospital stay and readmission rate. J Pediatr. 1995;127:758-766

3. Soskolne EL, Schumacher R, Fyock C, Young ML, Schork A. The effect of early discharge and other factors on readmission rates of newborns. Arch Pediatr Adolesc Med. 1996;150:373-379

4. Liu LL, Clemens CJ, Shay DK, Davis RL, Novack AH. The safety of newborn early discharge: the Washington State experience. JAMA. 1997; 278:293-298

5. Grupp-Phelan J, Taylor JA, Liu LL, Davis RL. Early newborn hospital discharge and readmission for mild and severe jaundice. Arch Pediatr Adolesc Med. 1999;153:1283-1288

6. Seidman DS, Stevenson DK, Ergaz Z, Gale R. Hospital readmission due to neonatal hyperbilirubinemia. Pediatrics. 1995;96:727-729

7. Braveman P, Egerter S, Pearl M. Early discharge of newborns and mothers: a critical review of the literature. Pediatrics. 1995;96:716-726

8. Brown AK, Damus K, Kim MH, et al. Factors relating to readmission of term and near term neonates in the first two weeks of life. J Perinat Med. 1999;27:263-275

9. Britton JR, Britton HL, Beebe SA. Early discharge of the newborn: a continued dilemma. Pediatrics. 1994;94:291-294

10. Catz C, Hanson JW, Simpson L, Yaffe SJ. Summary of workshop: early discharge and neonatal hyperbilirubinemia. Pediatrics. 1995;96:743-745

11. Conrad PD, Wilkering RB, Rosenberg AA. Safety of newborn discharge in less than 36 hours in an indigent population. Am J Dis Child. 1989; 143:98-101

12. Alpay F, Sarici SU, Tosuncuk HD, Serdar MA, Inanc N, Gokcay E. The value of first-day bilirubin measurement in predicting the development of significant hyperbilirubinemia in healthy term newborns. Pediatrics. 2000;106(2). Available at: http://www.pediatrics.org/cgi/content/ full/106/2/e16

13. Bhutani VK, Johnson LH, Sivieri EM. Universal newborn bilirubin screening [abstract]. Pediatr Res. 1997;41:191

14. Seidman DS, Ergaz Z, Paz I, et al. Predicting the risk of jaundice in fullterm healthy newborns: a prospective population-based study. I Perinatol. 1999;19(8, pt 1):564-567

15. Bhutani VK, Johnson L, Sivieri EM. Predictive ability of a predischarge hour-specific serum bilirubin for subsequent significant hyperbilirubinemia in healthy term and near-term newborns. Pediatrics. 1999;103: 6-14

16. Zipursky A, Bowman JM. Isoimmune hemolytic disease. In: Nathan DG, Oski FA, eds. Hematology of Infancy and Childhood. 4th ed. Philadelphia, PA: WB Saunders; 1993:44-74

17. American Academy of Pediatrics, Provisional Committee for Quality Improvement and Subcommittee on Hyperbilirubinemia. Practice parameter: management of hyperbilirubinemia in the healthy term newborn. Pediatrics. 1994;94:558-565

18. Sarici SU, Alpay F, Unay B, Ozcan O, Gokcay E. Double versus single phototherapy in term newborns with significant hyperbilirubinemia. $J$ Trop Pediatr. 2000;46:36-39

19. Alpay F, Sarici SU, Okutan V, Erdem G, Ozcan O, Gokcay E. High-dose intravenous immunoglobulin therapy in neonatal immune haemolytic jaundice. Acta Paediatr. 1999;88:216-219

20. Maisels MJ, Newman TB. Kernicterus in otherwise healthy, breast-fed term newborns. Pediatrics. 1995;96:730-733

21. Penn AA, Enzman DR, Hahn JS, Stevenson DK. Kernicterus in a full term infant. Pediatrics. 1994;93:1003-1006

22. Whyte J, Graham H. Prediction of the severity of ABO hemolytic disease of the newborn by cord blood tests. Acta Paediatr Scand. 1981;70:217-222

23. Levine DH, Meyer HB. Newborn screening for ABO hemolytic disease. Clin Pediatr. 1985;24:391-394

24. McDonnell M, Hannam S, Devane SP. Hydrops fetalis due to ABO incompatibility. Arch Dis Child Fetal Neonatal Ed. 1998;78:F220-F221

25. Ozolek JA, Watchko JF, Mimouni F. Prevalence and lack of clinical significance of blood group incompatibility in mothers with blood type A or B. J Pediatr. 1994;125:87-91

26. Maisels MJ. Neonatal hyperbilirubinemia. In: Klaus MH, Fanaroff AA, eds. Care of the High-Risk Neonate. Philadelphia, PA: WB Saunders; 2001:331-332

27. Katz MA, Kanto WP Jr, Korotkin JH. Recurrence rate of ABO hemolytic disease of the newborn. Obstet Gynecol. 1982;59:611-614 


\section{An Early (Sixth-Hour) Serum Bilirubin Measurement Is Useful in Predicting the Development of Significant Hyperbilirubinemia and Severe ABO Hemolytic Disease in a Selective High-Risk Population of Newborns With ABO Incompatibility}

S. Ümit Sarici, Murat Yurdakök, Muhittin A. Serdar, Olcay Oran, GÜlsen Erdem, GÜlsevin Tekinalp and Sule Yigit

Pediatrics 2002;109; 53

DOI: $10.1542 /$ peds.109.4.e53

\section{Updated Information \& Services}

References

Subspecialty Collections

Permissions \& Licensing

Reprints including high resolution figures, can be found at: http://pediatrics.aappublications.org/content/109/4/e53

This article cites 24 articles, 10 of which you can access for free at: http://pediatrics.aappublications.org/content/109/4/e53\#BIBL

This article, along with others on similar topics, appears in the following collection(s):

\section{Fetus/Newborn Infant}

http://www.aappublications.org/cgi/collection/fetus:newborn_infant_ sub

Hyperbilirubinemia

http://www.aappublications.org/cgi/collection/hyperbilirubinemia_su b

Information about reproducing this article in parts (figures, tables) or in its entirety can be found online at:

http://www.aappublications.org/site/misc/Permissions.xhtml

Information about ordering reprints can be found online: http://www.aappublications.org/site/misc/reprints.xhtml 


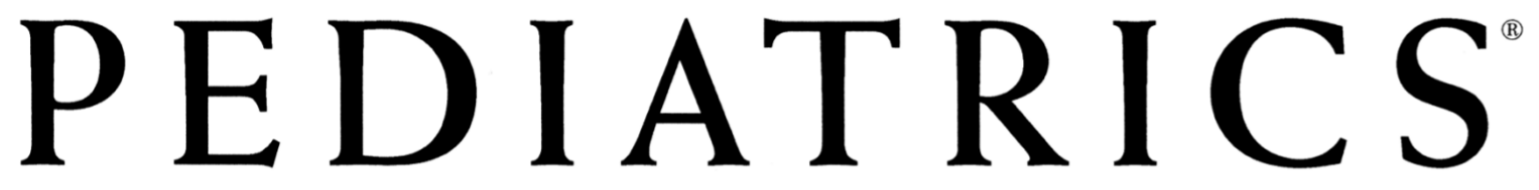

OFFICIAL JOURNAL OF THE AMERICAN ACADEMY OF PEDIATRICS

\author{
An Early (Sixth-Hour) Serum Bilirubin Measurement Is Useful in Predicting the \\ Development of Significant Hyperbilirubinemia and Severe ABO Hemolytic \\ Disease in a Selective High-Risk Population of Newborns With ABO \\ Incompatibility \\ S. Ümit Sarici, Murat Yurdakök, Muhittin A. Serdar, Olcay Oran, GÜlsen Erdem, \\ GÜlsevin Tekinalp and Sule Yigit \\ Pediatrics 2002;109; 53 \\ DOI: $10.1542 /$ peds.109.4.e53
}

The online version of this article, along with updated information and services, is located on the World Wide Web at: http://pediatrics.aappublications.org/content/109/4/e53

Pediatrics is the official journal of the American Academy of Pediatrics. A monthly publication, it has been published continuously since 1948 . Pediatrics is owned, published, and trademarked by the American Academy of Pediatrics, 141 Northwest Point Boulevard, Elk Grove Village, Illinois, 60007. Copyright $\odot 2002$ by the American Academy of Pediatrics. All rights reserved. Print ISSN: 1073-0397. 